\title{
PELATIHAN PENYUSUNAN PERATURAN DESA UNTUK APARATUR DESA DAN BADAN PERMUSYAWARATAN DESA GUNA MENINGKATKAN KOMPETENSI DALAM MENCIPTAKAN PRODUK HUKUM YANG IDEAL
}

\author{
Moch. Abdul Wachid, Evi Damayanti ${ }^{\star}$ \\ evidama8@gmail.com \\ Prodi Hukum, Fakultas Hukum, Universitas Wisnuwardhana Malang \\ Diterima 12 April 2020, dipublikasikan 31 Oktober 2020
}

\begin{abstract}
Abstrak
Dalam tata kelola pemerintahan desa, Peraturan Desa sangat krusial karena menjadi dasar hukum bagi pelaksanaan berbagai program dan kegiatan desa. Kegiatan pelatihan ini bertujuan untuk perbaikan mekanisme penyusunan peraturan desa serta peningkatan kemampuan aparatur desa dan Badan Permusyawaratan Desa (BPD) dalam penyusun peraturan desa. Metode yang digunakan adalah PAR (Participatory Action Research) yang terdiri dari beberapa rangkaian tahapan yaitu mulai dari perencanaan, pelaksanaan dan evaluasi. Dari hasil pendalaman diketahui permasalahan terkategori sebagai berikut: (a) Penyusunan rancangan peraturan desa belum ditetapkan pada RKP Desa; (b) Teknik penyusunan masih rendah dan belum sistematis; (c) Kecenderungan pola budaya paternalistik, pelaksanaan evaluasi kurang maksimal. Dari berbagai permasalahan tersebut, maka perlu adanya pelaksanaan kegiatan pelatihan penyusunan Peraturan Desa untuk aparatur desa dan BPD guna meningkatkan kompetensi dalam menciptakan produk hukum yang ideal. Adapun hasil yang diharapkan dari pelatihan ini adalah adanya perbaikan mekanisme penyusunan peraturan desa yang ditandai dengan meningkatnya kemampuan para aparatur desa dan BPD dalam membuat produk hukum yang ideal untuk mengakomodir kebutuhan masyarakat desa pada khususnya dan dapat bermanfaat bagi tata kelola pemerintahan desa pada umumnya.
\end{abstract}

Kata Kunci: Pelatihan, Penyusunan, Peraturan Desa, Produk Hukum, Ideal

\section{PENDAHULUAN}

Kelahiran Undang-Undang Nomor 6 Tahun 2014 tentang Desa membawa perubahan yang signifikan bagi eksistensi desa terutama dalam hal kemandirian mengatur urusan atau otonomi desa. Pasal 1 Undang-Undang Nomor 6 Tahun 2014 tentang Desa menyatakan bahwa Pemerintahan Desa adalah "penyelenggaraan urusan pemerintahan dan kepentingan masyarakat setempat dalam sistem pemerintahan Negara Kesatuan Republik Indonesia". Salah satu bentuk otoritas dan kemandirian yang dapat dilihat adalah adanya Peraturan Desa. Peraturan desa merupakan penjabaran lebih lanjut dari peraturan perundang-undangan yang lebih tinggi kedudukannya dengan memperhatikan kondisi sosial masyarakat desa setempat (Widjaja, 2003; Kaputra, 2013). Dalam rangka mewujudkan tatanan yang tertib di bidang Peraturan Perundang-undangan di Indonesia, telah ditetapkan Undang-Undang Nomor 12 Tahun 2011 Tentang Pembentukan Peraturan Perundang Undangan. Undang-Undang Nomor 12 Tahun 2011 Tentang Pembentukan Peraturan Perundang-Undangan, tidak lagi menyebutkan secara eksplisit Peraturan Desa sebagai salah satu jenis dan hierarki Peraturan Perundang-undangan.

Menurut Budiono (2015), penyelenggaraan urusan pemerintahan menjadi kewenangan desa, sehingga dalam banyak hal harus diimplementasikan dalam Peraturan Desa untuk memberikan pengaturan secara jelas mengenai penyelenggaraan urusan pemerintahan Desa. Hal ini dapat kita amati ketika proses menetapkan Anggaran Pendapatan dan Belanja Desa (APBDes), pengelolaan keuangan desa yang digunakan untuk mendanai penyelenggaraan Pemerintahan Desa dan pemberdayaan masyarakat desa harus dituangkan dalam Peraturan Desa Tentang APB Desa, dan penetapannya dilakukan oleh Badan Permusyawaratan Desa sebagai lembaga pemerintahan desa yang tugasnya menampung dan menyalurkan aspirasi masyarakat bersama Kepala Desa. Kemudian 
membuat aturan formal tentang Rencana Pembangunan Jangka Menengah Desa (RPJMDes), menetapkan susunan organisasi dan tata kerja pemerintahan desa, hakikatnya masih banyak peraturan desa lainnya yang harus dibentuk dan ditetapkan oleh Pemerintahan Desa dengan Peraturan Desa. Pemberian otonomi kepada daerah diikuti dengan kewajiban untuk meningkatkan kualitas kehidupan masyarakat dan mengembangkan sumber daya produktif di daerah.

Dalam Pasal 1 angka 8 Peraturan Pemerintah Republik Indonesia Nomor 72 Tahun 2005 tentang Pemerintahan Desa, disebutkan bahwa perwujudan demokrasi di Desa dibentuk Badan Permusyawaratan Desa (BPD) yang sesuai dengan budaya yang berkembang di Desa yang bersangkutan, yang berfungsi sebagai lembaga legislasi dan pengawasan dalam hal pelaksanaan Peraturan Desa, Anggaran Pendapatan dan Belanja Desa dan Keputusan Kepala Desa. Badan Permusyawaratan Desa atau yang disebut dengan nama lain, selanjutnya disingkat BPD, adalah lembaga yang merupakan perwujudan demokrasi dalam penyelenggaraan pemerintahan desa sebagai unsur penyelenggara pemerintahan desa. Oleh karena itu BPD sebagai wakil rakyat atau wakil penduduk desa memiliki beberapa fungsi, yang diantaranya berfungsi untuk menetapkan Peraturan Desa bersama-sama dengan kepala Desa, serta menampung dan menyalurkan aspirasi masyarakat.

Dalam tata kelola pemerintahan desa, Peraturan Desa menjadi sangat krusial karena menjadi dasar hukum bagi pelaksanaan berbagai program dan kegiatan desa. Berdasarkan analisis situasi diketahui permasalahan yang dihadapi oleh Pemerintah Desa Poncokusumo Kabupaten Malang adalah sebagai berikut: (a) Penyusunan rancangan peraturan desa tidak sesuai prosedur karena belum ditetapkan pada RKP Desa; (b) Teknik penyusunan masih rendah dan belum sistematis; (c) Kecenderungan pola budaya paternalistik, pelaksanaan evaluasi terhadap peraturan desa kurang maksimal. Dari paparan analisis masalah diatas, maka dapat disimpulkan bahwa dari rangkaian proses penyusunan rancangan peraturan desa hingga tahap penetapannya masih ditemukan ketidaksesuaian prosedur teknis penyusunan peraturan desa. Hal tersebut dikarenakan kurangnya pengetahuan dan pemahaman terhadap prosedur teknis penyusunan peraturan desa. Atas dasar itulah, maka perlu dilakukan kegiatan Pelatihan penyusunan Peraturan Desa untuk Aparatur Desa dan Badan Permusyawaratan Desa di Desa Poncokusumo, Kabupaten Malang.

\section{METODE}

Pelaksanaan pengabdian dengan disusun dalam agenda pelatihan dan pendampingan (Wiradimadja et al., 2019). Kegiatan ini menggunakan metode ceramah dan PAR (Participatory Action Research) dalam penyusunan peraturan desa. Metode ceramah digunakan untuk memberikan penjelasan secara langsung pada saat pelatihan mengenai teknis penyusunan peraturan desa. Objek sasaran dalam kegiatan pelatihan ini adalah 20 orang yang terdiri dari Aparatur Desa yang termasuk didalamnya yaitu Kepala Desa beserta jajarannya dan Badan Perwakilan Desa (BPD). Indikator keberhasilan yang diharapkan dari metode ini adalah adanya perbaikan mekanisme penyusunan peraturan desa yang dihasilkan oleh Pemerintah Desa Poncokusumo Kabupaten Malang.

Kemudian tahapan kegiatan dilaksanakan dengan metode PAR (Participatory Action Research) guna menyerap aspirasi masyarakat dalam proses penyusunan peraturan desa (Sukriono dan Rapita, 2018; Habibi dkk, 2019). Metode memiliki beberapa tahapan seperti tertuang dalam gambar bagan 1. 


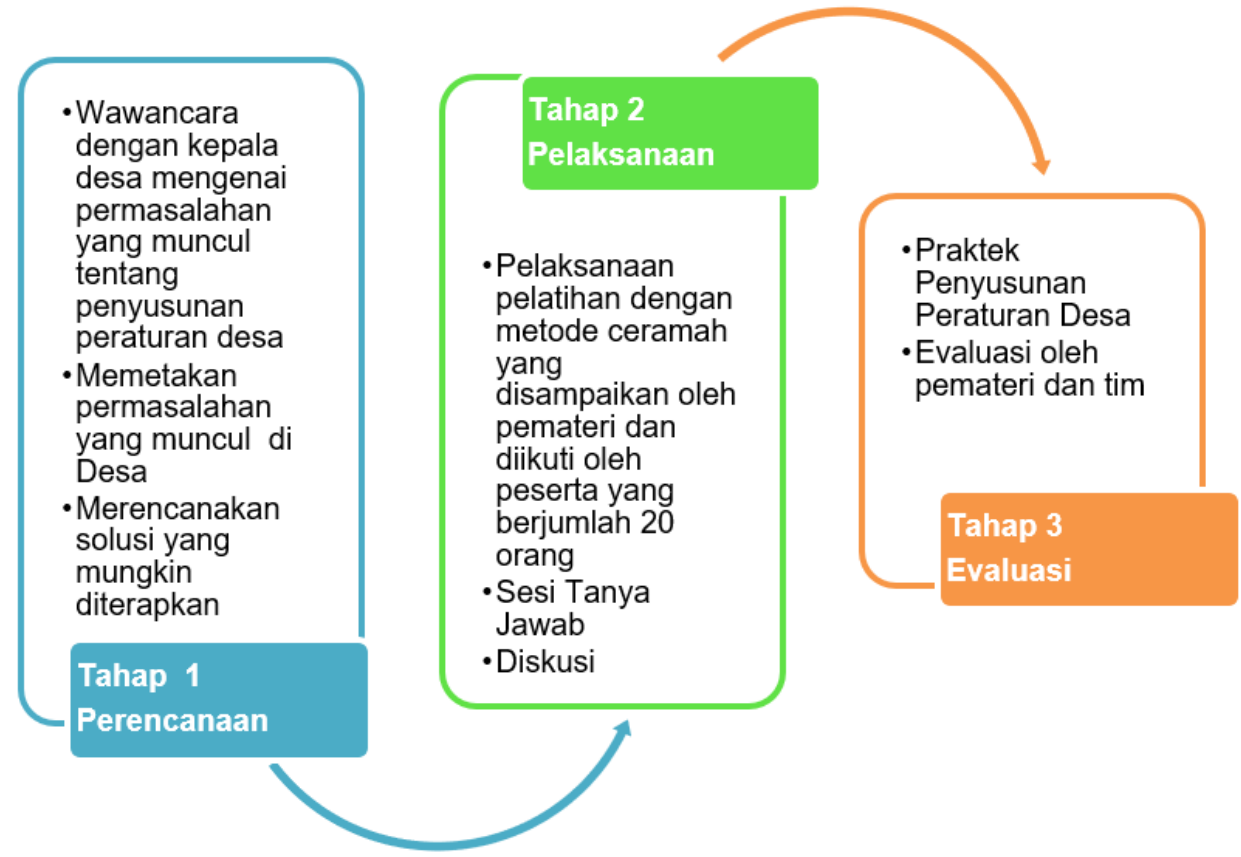

Gambar 1 Bagan Tahapan Kegiatan Pengabdian

Penjelasan masing-masing tahapan kegiatan adalah: 1) Tahap perencanaan yaitu tim melakukan penggalian data guna menganalisis situasi dan permasalahan yang muncul di lapangan. Hal ini digunakan sebagai dasar dalam memetakan permasalahan yang ada. Tahapan ini diawali dengan wawancara bersama Kepala Desa Poncokusumo untuk menggali permasalahan yang muncul terkait penyusunan peraturan desa. Setelah data permasalahan diperoleh, kegiatan dilanjutkan dengan pemetaan permasalahan dan solusi yang mungkin diterapkan; 2) Tahap pelaksanaan dilakukan dengan kegiatan inti yaitu pelaksanaan pelatihan penyusunan peraturan desa dengan metode ceramah dan kemudian dilanjutkan dengan sesi tanya jawab dan diskusi guna penyerapan aspirasi masyarakat. Tingkat keterserapan aspirasi masyarakat dapat dilihat dari keterwakilan gagasan yang disampaikan oleh Badan Perwakilan Desa (BPD) melalui sesi diskusi dan tanya jawab peserta. Indikator keberhasilan pada tahap ini adalah adanya respon positif dari peserta pelatihan terhadap pelaksanaan kegiatan pelatihan; dan 3) Tahap evaluasi dilakukan dengan praktek langsung penyusunan peraturan desa hal ini bertujuan mengetahui tingkat penguasaan materi penyusunan peraturan desa pada saat pelatihan. Indikator keberhasilannya dapat diketahui dari adanya perbaikan mekanisme dan peningkatan kemampuan teknis penyusunan peraturan desa yang diaktualisasikan dalam produk hukum peraturan desa.

\section{HASIL DAN PEMBAHASAN}

Hasil pelaksanaan kegiatan pengabdian dengan pendekatan PAR (Participatory Action Research) pada tahap perencanaan tim mengetahui permasalahan yang muncul dalam penyusunan peraturan desa di Desa Poncokusumo Kabupaten Malang.

Penyusunan rancangan peraturan desa tidak sesuai prosedur karena belum ditetapkan pada RKP Desa. Hal ini diketahui dari hasil wawancara secara langsung dengan Bapak Moh. Afif selaku Kepala Desa yang menerangkan bahwa perencanaan penyusunan rancangan peraturan desa harus ditetapkan dalam Rencana Kerja Pemerintah Desa (RKP), namun dalam pelaksanaannya belum berjalan maksimal. Dampak yang ditimbulkan dari hal tersebut adalah terganggunya proses pembuatan RKP dan RPJMDes menjadi terbengkalai. Sebagaimana diketahui Dalam Pasal 5 ayat (1) Peraturan Menteri Dalam Negeri Nomor 111 Tahun 2014 dijelaskan bahwa perencanaan penyusunan rancangan Peraturan Desa ditetapkan oleh Kepala Desa dan BPD dalam Rencana Kerja Pemerintah Desa. 
Rencana Kerja Pemerintah Desa merupakan penjabaran dari Rencana Pembangunan Jangka Menengah Desa untuk jangka waktu 1 (satu) tahun.

Teknik penyusunan masih rendah dan belum sistematis, dalam penerapannya secara yuridis normatif belum mengacu pada peraturan yang lebih tinggi diatasnya. Peraturan Desa Poncokusumo tentang APB Des tidak merujuk pada Peraturan Daerah Kabupaten Malang Nomor 7 Tahun 2007 Tentang Pembentukan dan Mekanisme Penyusunan Peraturan Desa. Untuk itulah seharusnya dalam pembentukan Peraturan Desa juga mengacu pada Peraturan Daerah Kabupaten Malang karena secara teritorial desa Poncokusumo termasuk dalam wilayah Kabupaten Malang. Hal tersebut perlu diperhatikan mengingat dalam pembentukan suatu peraturan tidak boleh bertentangan dengan peraturan yang sederajat maupun peraturan yang lebih tinggi, tujuannya tidak lain adalah supaya tercipta sinkronisasi dan harmonisasi antara peraturan yang lebih rendah dengan peraturan yang lebih tinggi maupun dengan yang sederajat.

Kecenderungan pola budaya paternalistik serta pelaksanaan evaluasi terhadap peraturan desa kurang maksimal. Budaya juga termasuk faktor yang mempengaruhi dalam proses pembentukan Peraturan Desa. Pola budaya paternalistik yang cenderung mengikuti apa saja kata pimpinan menjadikan partisipasi politik dari masyarakat dalam pembuatan Peraturan Desa sangat terbatas begitupun dalam proses evaluasi terhadap peraturan desa juga masih sangat rendah.

Pada tahap pelaksanaan kegiatan pelatihan penyusunan peraturan desa, peserta berjumlah 20 orang yang terdiri dari Pemerintah desa dalam hal ini kepala desa beserta jajarannya, BPD dan beberapa tokoh masyarakat. Pada tahap awal, pemateri menyampaikan materi mengenai teknis penyusunan peraturan desa. Pemateri juga memberikan contoh menyusun peraturan desa hingga kemudian dilanjutkan dengan sesi tanya jawab dan diskusi.

Pada tahap evaluasi, peserta pelatihan diberi kesempatan untuk mempraktekkan langsung menyusun peraturan desa, namun peserta member masukan yaitu memperbaiki peraturan desa yang sudah ada. Masukan dari peserta disetujui oleh tim dan narasumber, peraturan desa yang sudah ada dievaluasi dan dilakukan perbaikan. Hasil evaluasi tersaji dalam tabel 1.

Tabel 1. Hasil Evaluasi Pelatihan Penyusunan Peraturan Desa

\begin{tabular}{clc}
\hline No. & \multicolumn{1}{c}{ Aspek } & Prosentase Ketercapaian \\
\hline 1. & $\begin{array}{l}\text { Penguasaan materi penyusunan } \\
\text { peraturan desa }\end{array}$ & $90 \%$ \\
2. & $\begin{array}{l}\text { Pemahaman teknis/ mekanisme } \\
\text { penyusunan }\end{array}$ & $90 \%$ \\
3. & $\begin{array}{l}\text { Partisipasi peserta pelatihan dalam } \\
\text { menyampaikan gagasan }\end{array}$ & $85 \%$ \\
4. & $\begin{array}{l}\text { Praktek penyusunan peraturan desa } \\
\text { oleh peserta pelatihan }\end{array}$ & $90 \%$ \\
\hline
\end{tabular}

Dari hasil evaluasi kegiatan pelatihan diatas, dapat diketahui bahwa terjadi peningkatan kompetensi dan perbaikan mekanisme yang ditunjukkan dalam proses penyusunan peraturan desa. Pemahaman dan penguasaan materi terserap dengan baik. Partisipasi peserta pelatihan dalam sesi tanya jawab berjalan dengan baik dan diskusi hidup. Sejalan dengan hal tersebut dalam penerapannya, praktek penyusunan peraturan desa yang dilakukan dengan memperbaiki peraturan desa yang sudah ada dan mengevaluasi hasil kerja menunjukkan hasil yang maksimal.

\section{KESIMPULAN}

Berdasarkan rangkaian kegiatan pengabdian yang dilaksanakan dari tahap perencanaan, pelaksanaan pelatihan hingga tahap evaluasi, dapat ditarik kesimpulan bahwa: (1) peserta pelatihan yang terdiri dari Aparatur Desa dan Badan Permusyawaratan Desa (BPD) mampu memahami dan menguasai materi mengenai teknis penyusunan peraturan desa; (2) dengan terlaksanakannya kegiatan pelatihan penyusunan peraturan desa dapat meningkatkan kompetensi Aparatur Desa dan BPD dalam menyusun peraturan desa sehingga di Desa Poncokusumo Kabupaten Malang. 
Saran yang dapat diberikan dari hasil kegiatan pengabdian ini yaitu diharapkan adanya keberlanjutan proses diskusi dan penyampaian gagasan yang baik guna terciptanya peraturan desa yang bagus. Sehingga proses yang telah dilalui dalam pelatihan tidak berhenti dan diskusi tetap terpelihara. Diharapkan juga adanya evaluasi dan pendampingan dari pihak kabupaten setempat guna monitoring produk hukum yang dihasilkan di Desa Poncokusumo Kabupaten Malang.

\section{UCAPAN TERIMAKASIH}

Terimakasih ditujukan kepada Universitas Wisnuwardhana Malang selaku pihak yang mendanai terselenggaranya kegiatan ini serta seluruh tim yang terlibat, pemateri dan peserta, pemerintah desa Poncokusumo terkhusus Kepala Desa yang telah berkenan mengijinkan untuk terselenggaranya kegiatan pelatihan ini dengan baik dan lancar.

\section{DAFTAR PUSTAKA}

Budiono, P. (2015). Implementasi Kebijakan Badan Usaha Milik Desa (Bumdes) Di Bojonegoro (Studi di Desa Ngringinrejo Kecamatan Kalitidu Dan Desa Kedungprimpen Kecamatan Kanor). Jurnal Politik Muda, 4(1), 116-125.

Habibi, M.M., Sukriono, D., Rapita, D.D., Sudirman. (2019). Pendampingan Pembentukan Standar Pelayanan Publik Pemerintah Desa Sebagai Upaya Mewujudkan Good Village Governance. Jurnal Praksis dan Dedikasi Sosial, 4(1):19-27.

Kaputra, Iswan. 2013. Dampak Otonomi Daerah di Indonesia, Jakarta: Yayasan Pustaka Obor Indonesia.

Peraturan Daerah Kabupaten Malang Nomor 7 Tahun 2019 Tentang Perlindungan Pekerja Migran Indonesia Dan Keluarganya. Malang: Sekretaris Daerah Kabupaten Malang

Peraturan Pemerintah Republik Indonesia Nomor 72 Tahun 2005 tentang Pemerintahan Desa. Jakarta: Kementerian Hukum dan Hak Asasi Manusia Republik Indonesia

Sukriono, D., Rapita, D.D. (2018). Pelatihan Pembuatan Produk Hukum Desa Di Pemerintahan Desa Kecamatan Sumberpucung Kabupaten Malang. Jurnal Praksis dan Dedikasi Sosial. 1(1):10-20

Undang-undang Republik Indonesia Nomor 6 Tahun 2014 tentang Desa. Jakarta: Kementerian Hukum dan Hak Asasi Manusia Republik Indonesia

Undang-undang Republik Indonesia Nomor 12 Tahun 2012 tentang Pembentukan Peraturan Perundang-Undangan. Jakarta: Kementerian Hukum dan Hak Asasi Manusia Republik Indonesia

Undang-undang Republik Indonesia Nomor 111 Tahun 2014 tentang Pedoman Teknis Peraturan Desa. Jakarta: Kementerian Hukum dan Hak Asasi Manusia Republik Indonesia

Widjaja, HAW. (2003). Otonomi Desa Merupakan Otonomi Yang Asli, Bulat, dan Utuh, Jakarta: Raja Grafindo Persada.

Wiradimadja, A., Kurniawan, B., \& Sukamto. (2019). PELATIHAN DAN PENDAMPINGAN PENYUSUNAN PTK (PENELITIAN TINDAKAN KELAS) BAGI GURU IPS SMP/MTS MALANG RAYA. Jurnal Praksis Dan Dedikasi Sosial (JPDS), 2(1). 